\title{
Pengaruh Tenaga Kerja, dan Pengeluaran Pemerintah Terhadap Pertumbuhan Ekonomi dan Kemiskinan Jurnal Ecces
}

\author{
Ilyas \\ Jurusan Ilmu Ekonomi Studi Pembangunan (IESP) \\ Fakultas Ekonomi dan Bisnis Universitas Haluleo Kendari \\ E-mail : ilyasalimudin86@gmail.com
}

\section{Abstrak: Pengaruh Tenaga Kerja, dan Pengeluaran Pemerintah Terhadap Pertumbuhan Ekonomi dan Kemiskinan}

Salah satu indikator penting untuk melihat kinerja pembanguanan sebuah negara atau daerah adalah dengan melihat kinerja pertumbuhan ekonominya. Semakin meningkat pertumbuhan ekonominya berarti semakin baik pula kinerja pembangunan begitu pula sebaliknya. Atas dasar ini maka setiap negara atau daerah berusaha semaksimal mungkin untuk mengakselerasi pertumbuhan ekonominya.Penelitian ini bertujuan untuk pengaruh tenaga kerja dan pengeluaran pemerintah terhadap pertumbuhan ekonomi di Kabupaten Sinjai. Serta untuk mengetahui pengaruh pertumbuhan ekonomi terhadap kemiskinan di Kabupaten Sinjai.Variabel-variabel yang diamati dalam penelitian ini meliputi: tenaga kerja dan pengeluaran pemerintah sebagai variabel bebas serta pertumbuhan ekonomi dan kemiskinan sebagai variabel bebas.Metode penelitian yang digunakan adalah penelitian kuntitatif. Data yang digunakan adalah data sekunder, time series. Sumber data utama berasal dari publikasi Biro Pusat Statistik Kabupaten Sinjai dan publikasi lainnya yang terkait penulisan. Teknik analisis data yang digunakan adalah Structural Equation Model (SEM), dengan menggunakan alat bantu analisis yakni eviews.Dari hasil uji statistik ditemukan bahwa tenaga kerja tidak berpengaruh signifikan terhadap pertumbuhan ekonomi. Sementara pengeluaran pemerintah berpangaruh positif dan signifikan terhadap pertumbuhan ekonomi. Selanjutnya pertumbuhan ekonomi berpengaruh terhadap kemiskinan, dan hubungannya negatif, artinya ketika ertumbuhan ekonomi mengalami peningkatan maka akan menurunkan angka kemiskinan begitupula sebaliknya.

Kata Kunci: Tenaga kerja, pengeluaran pemerintah, pertumbuhan ekonomi dan kemiskinan. 


\section{Abstract: Effect of Labor, and Government Expenditures on Economic Growth and poverty}

One important indicator to understand the performance of developing a country or region, to look at the performance of its economic growth. Increasing economic growth means better development performance and vice versa. On this basis, every country or region strives to accelerate its economic growth. This study aims to influence the labourforce and government expenditure on economic growth in Sinjai District. As well as to determine the effect of economic growth on poverty in Sinjai Regency. The variables observed in this study include; labor and government expenditure as independent variables and economic growth and poverty as independent variables. The research method used is quantitative research. The data used is secondary data, time series. The main data sources come from the publications of the Sinjai Regency Central Bureau of Statistics and other publications related to writing. The data analysis technique used is Structural Equation Model (SEM), using analytical tools namely eviews. From the results of statistical tests it was found that labor did not significantly influence economic growth. While government spending has a positive and significant effect on economic growth. Furthermore, economic growth has an effect on poverty, and its relationship is negative, meaning that when economic growth increases, it will reduce poverty as well as vice versa.

Keywords: Labour, Government Expenditure, growth and poverty.

\section{PENDAHULUAN / INTRODUCTION}

Trend peningkatan tenaga kerja, pengeluaran pemerintah mengalami peningkatan dari tahun ke tahun, sementara pertumbuhan ekonomi bergerak fluktuatif dan angka kemiskinan yang tidak mengalami perbaikan yang berarti, hal tersebut menunjukkan kegiatan ekonomi yang terjadi di Kabupaten Sinjai tidak begitu impresif. Di Kabupaten Sinjai sendiri, dalam beberapa tahun terakhir terjadi peningkatan penduduk. Untuk tahun 2010 saja jumlah penduduk di Kabupaten Sinjai berjumlah 228. 879 jiwa, meningkat cukup dari lima tahun sebelumnya 222. 220 jiwa. Ini berarti terjadi peningkatan tenaga kerja yang tersedia untuk pembangunan. Selain itu anggaran atau pengeluaran pemerintah yang selalu dialokasikan untuk belanja modal setiap tahun terus meningkat. Pada tahun 2009 belanja pemerintah masih sebesar Rp. 452.845 milyar, meningkat cukup signifikan dalam lima tahun kemudian menjadi Rp. 644.523 milyar. Pada saat yang sama, pertumbuhan ekonomi meski berfluktuasi namun berada dalam posisi peningkatan. Di tahun 2009 berada pada posisi 7,02\% kemudian menurun pada tahun 2010 menjadi 6,03. Selanjutnya kembali mengalami peningkatan pada tahun 2013 menjadi 7,29\%. 
Ilyas, Pengaruh Tenaga Kerja, dan Pengeluaran ...

Selanjutnya persoalan kemiskinan yang persentasenya sebesar 9,28\% pada tahun 2013 yang sebenarnya mengalami penurunan dari tahun sebelumnya yang masih di posisi 9,77\%. Kinerja ini patut diapresiasi. Namun demikian problem kemiskinan yang persentasenya hampir di angka dua digit menujukkan bahwa kemiskinan masih tinggi karenanya harus dituntaskan, sampai pada posisi $0 \%$. Apalagi dalam konsep Suistanable Development Goals (SDGs) yang digagas sekarang dan meruapakan pengganti dari konsep Millenium Development Goals (MDGs) memiliki tujuan untuk mengentaskan kemiskinan secara keseluruhan di muka bumi ini. Berangkat dari latar belakang di atas penelitian ini mencoba menjawab problem tersebut dengan mengangkat tema "Pengaruh Tenaga Kerja, dan Pengeluaran Pemerintah Terhadap Pertumbuhan Ekonomi dan Kemiskinan Di Kabupaten Sinjai". Ada tiga tujuan yang ingin dicapai dalam penelitian ini yaitu pertama untuk mengetahui pengaruh tenaga kerja terhadap pertumbuhan ekonomi di Kabupaten Sinjai. Kedua, mengetahui pengaruh pengeluaran pemerintah terhadap pertumbuhan ekonomi di Kabupaten Sinjai. Terakhir, mengetahui pengaruh pertumbuhan ekonomi terhadap kemiskinan. Salah satu indikator penting untuk melihat kinerja pembanguanan sebuah negara atau daerah adalah dengan melihat kinerja pertumbuhan ekonominya. Semakin meningkat pertumbuhan ekonominya berarti semakin baik pula kinerja pembangunan begitu pula sebaliknya. Atas dasar ini maka setiap negara atau daerah berusaha semaksimal mungkin untuk mengakselerasi pertumbuhan ekonominya. Pertumbuhan ekonomi secara nasional menggunakan indikator Produk Domestik Bruto (PDB), yakni jumlah barang dan jasa yang diproduksi oleh sebuah negara pada periode tertentu yang biasanya satu tahun. Sedangkan untuk tingkatan daerah, baik level provinsi maupun kabupaten atau kota menggunakan indikator Produk Domestik Regional Brutto (PDRB).

Pertumbuhan ekonomi berarti perkembangan atau peningkatan kegiatan dalam perekonomian yang menyebabkan barang dan jasa yang diproduksi bertambah atau berkurang sehingga kemakmuran daerah dan masyarakat dapat meningkat atau sebaliknya. Sedangkan laju pertumbuhan ekonomi merupakan kenaikan dalam PDRB tampa memandang apakah kenaikan itu lebih besar atau lebih kecil dari tingkat pertumbuhan penduduk dan apakah ada perubahan atau tidak dalam struktur ekonomi (Sukirno, 1994). Lain daripada itu, sejak digulirkan otonomi daerah dengan ditetapkannya Undang-Undang No. 22 tahun 1999 yang direvisi oleh Undang-Undang No. 32 tahun 2004 tentang Pemerintahan Daerah yang intinya menekankan bahwa pemerintah daerah mempunyai 
kewenangan untuk mengatur dan mengelola berbagai urusan penyelenggaraan pemerintahan bagi kepentingan dan kesejahteraan masyarakat daerah yang bersangkutan. Sedangkan dalam hal pembiayaan dan keuangan daerah pasca desentralisasi fiskal sebagaimana diatur dalam Undang-Undang No 25 tahun 1999 yang kemudian direvisi dengan Undang-Undang No. 33 tahun 2004 tentang Perimbangan Keuangan antara Pemerintah Pusat dan Pemerintah Daerah menyebutkan bahwa pembiayaan pembangunan tidak hanya dilakukan oleh pemrintah saja, tetapi juga didukung oleh pelaku pembangunan dengan pemanfaatan sumber daya yang ada dalam wilayah secara optimal untuk mendukung pelaksanaan otonomi daerah mengingat adanya keterbatasan pendanaan pemerintah.

Adanya dua Undang-Undang ini mengubah pola sistem pemerintahan daerah dari sistem desentralisasi menjadi sentralisasi. Filosofi lahirnya aturan ini berangkat dari kesadaran bahwa konsep pembangunan yang selama ini sangat sentralistik, semua mesti diatur oleh pusat telah mematikan potensi kreatif di daerah. bahwa yang paling mengetahu persoalan di daerah dan bagaimana solusi yang terbaik adalah pemerintah daerah yang realitasnya memang paling dekat masyarakat di daerah. Bukan pemerintah pusat. Begitupula dengan persoalan keuangan daerah. Adanya Undang-Undang No. 33 ini kemudian alas hukum bagi pemerintahan daerah untuk menemukan dan mengembangkan potensi yang dimiliki untuk mengakselerasi pertumbuhan ekonomi yang pada akhirnya meningkatkan kesejahteraan dan mereduksi kemiskinan. Harapan dari desentralisasi fiskal ini adalah bagaimana seluruh pemangku kepentingan di daerah mampu memanfaatkan potensi yang ada seperti tenaga kerja, sumber daya alam, modal serta potensi lainnya untuk dimanfaatkan semaksimal mungkin untuk mengakselerasi pembangunan di daerah.

Sebagaimana teori pertumbuhan ekonomi yang menjelaskan bahwa pertumbuhan ekonomi dipengaruhi oleh beberapa faktor yaitu konsumsi rumah tangga (C), Investasi swasta (I), pengeluaran pemerintah (G) serta sektor luar negeri (X-). Atau biasa dituliskan $\mathrm{Y}=\mathrm{C}+\mathrm{I}+\mathrm{G}+(\mathrm{X}-\mathrm{M})$. Dengan melihat persamaan ini maka pemerintah dapat mengakselerasi pertumbuhan ekonomi jika melakukan intervensi pada keempat variabel tersebut. Mendorong konsumsi rumah tangga, meningkatkan investasi swasta, pengeluaran pemerintah dimaksimalkan, serta meningkatkan ekspor disaat yang sama mengurangi 
Ilyas, Pengaruh Tenaga Kerja, dan Pengeluaran ...

impor. Apabila pemerintah mampu melakukan ini dengan baik maka pertumbuhan ekonomi dapat diakselerasi. Selain itu juga persoalan-persoalan ekonomi seperti kemiskinan, ketimpangan, pengangguran dan yang lainnya dapat diselesaikan. Problem ekonomi ini, terkhusus kemiskinan sendiri merupakan permasalahan yang dihadapi oleh hampir semua negara, lebih khusus di negara berkembang seperti Indonesia. Dengan melihat kondisi ini dapat dipahami bahwa semangat yang mendasari desentralisasi fiskal ini adalah bagaimana keterlibatan daerah dalam pembangunan bangsa menjadi penting. Menumbuhkan kreatifitas di daerah serta membuka ruang partisipasi daerah yang lebih besar dalam pembangunan akan mempercepat terealisasinya tujuan bernegara.

Determinan pertumbuhan ekonomi adalah sumber daya manusia, baik dari sisi kuantitas maupun kualitas. Penduduk yang bertambah dari waktu ke waktu dapat menjadi faktor pendorong maupun penghambat pertumbuhan ekonomi. Penduduk yang bertambah akan memperbesar jumlah tenaga kerja, dan penambahan tersebut memungkinkan suatu daerah untuk meningkatkan produksi. Jumlah penduduk yang banyak pun merupakan pangsa pasar yang besar yang memungkinkan peningkatan konsumsi dan produksi sehingga dapat mendorong pertumbuhan ekonomi daerah. Namun, di sisi lain akibat buruk dari pertambahan penduduk terhadap pertumbuhan ekonomi adalah jikasumber daya manusia yang tersedia lebih dominan yang kurang berkualitas. Sehingga SDM tersebut tidak mampu mendorong produktivitas sehingga tidak akan mampu memacu pertumbuhan ekonomi. Bahkan bisa menjadi beban pembangunan. Belum lagi jika pertumbuhan SDM tidak dibarengi atau jauh lebih cepat dari pertumbuhan ekonomi. Hal ini berarti kelebihan jumlah penduduk tidak seimbang dengan faktor produksi lain yang tersedia dimana penambahan penggunaan tenaga kerja tidak akan menimbulkan penambahan dalam tingkat produksi.

Untuk penelitian ini diharapkan mampu memberikan manfaat teoritis maupun praktis. Manfaat teoritisnya adalah diharapkan mampu memberikan pemahaman dan memberikan rumusan pola hubungan tenaga kerja, dan pengeluaran pemerintah terhadap pertumbuhan ekonomi dan kemiskinan di daerah. Akan memberikan sumbangsih pemikiran serta memperluas khasanah teori dan kajian ekonomi daerah serta pengembangan ilmu ekonomi pembangunan dan perencanaan. Selain itu penelitian ini juga diharapkan dapat menjadi bahan informasi bagi pihak-pihak yang memerlukan khususnya bagi penelitianpenelitian selanjutnya. Sementara manfaat praktisnya bisa menjadi bahan informasi dan masukan bagi pengambil kebijakan dalam hal ini Pemerintah Daerah Kabupaten Sinjai, 
dalam menyusun dan merumuskan rencana dan strategi untuk meningkatkan pertumbuhan ekonomi serta mereduksi kemiskinan di Kabupaten Sinjai.

\section{TINJAUAN TEORITIK / LITERATURE REVIEW}

\section{Tenaga Kerja}

Adam Smith dalam Todaro (2003) mengungkapkan bahwa tokoh utama dari aliran ekonomi yang kemudian dikenal sebagai aliran klasik, yakni Adam Smith menganggap bahwa manusialah sebagai faktor produksi utama yang menentukan kemakmuran bangsabangsa. Alasannya, alam (tanah) tidak ada artinya kalau tidak ada sumber daya manusia yang pandai mengolahnya sehingga dapat bermanfaat bagi kehidupan. Smith juga melihat bahwa alokasi sumber daya manusia yang efektif adalah pemula pertumbuhan ekonomi. Setelah ekonomi tumbuh, akumulasi modal (fisik) baru mulai dibutuhkan untuk menjaga agar ekonomi tumbuh. Dengan kata lain, alokasi sumber daya manusia yang efektif merupakan syarat perlu necessary condition bagi pertumbuhan ekonomi. Adam Smith menekankan arti penting pembagian kerja bagi perkembangan ekonomi. Pembagian kerja menghasilkan perbaikan kemampuan produksi buruh. Setiap buruh menjadi lebih efisien daripada sebelumnya. Ia menghemat waktu. Ia mampu menemukan mesin baru dan berbagai proses baru dalam berproduksi. Akhirnya, produksi meningkatkan berbagai hal. Akan tetapi, pembagian kerja tergantung pada luas pasar.

Pertumbuhan penduduk dan angkatan kerja secara tradisional dianggap sebagai salah satu faktor positif yang memacu pertumbuhan ekonomi. Jumlah tenaga kerja yang lebih besar berarti ukuran pasar domestiknya lebih besar. Sedangkan, Lewis menyatakan bahwa angkatan kerja yang homogen dan tidak terampil dianggap bisa bergerak dan beralih dari sektor tradisional ke sektor modern secara lancar dan dalam jumlah terbatas. Dalam keadaan demikian penawaran tenaga kerja mengandung elastisitas yang tinggi. Meningkatnya permintaan atas tenaga kerja (dari sektor tradisional) bersumber pada ekspansi kegiatan sektor modern. Dengan demikian salah satu faktor yang berpengaruh terhadap pertumbuhan ekonomi adalah tenaga kerja.

Jumlah tenaga kerja yang lebih besar berarti akan menambah tingkat produksi, sedangkan pertumbuhan penduduk yang lebih besar berarti ukuran pasar domestiknya lebih 
Ilyas, Pengaruh Tenaga Kerja, dan Pengeluaran ...

besar. Dengan demikian, jumlah tenaga kerja yang besar dapat berarti menambah jumlah tenaga produktif. Oleh karena meningkatnya produktivitas tenaga kerja diharapkan akan meningkatkan produksi yang berarti pula meningkatakan pertumbuhan ekonomi.

Menurut Undang-Undang No. 13 tahun 2013 tentang Ketenagakerjaan, mendefinisikan tenaga kerja adalah setiap orang yang mampu melakukan pekerjaan guna menghasilkan barang dan jasa, baik untuk memenuhi kebutuhan sendiri maupun untuk masyarakat. Mengenai perumusan tenaga kerja, setiap negara memberikan batasan yang berbeda-beda. Misalnya, Amerika Serikat menetapkan batas minimal usia tenaga kerja 16 tahun dan India menetapkan antara 14-60 tahun, sementara Indonesia menetapkan usia 18 tahun atau lebih. Tenaga kerja (manpower) terdiri atas angkatan kerja dan bukan angkatan kerja. Angkatan kerja (labor force), terdiri atas golongan yang bekerja dan golongan yang menganggur serta yang mencari pekerjaan. Sedangkan, kelompok bukan angkatan kerja terdiri atas golongan yang masih sekolah, orang yang mengurus rumah tangga, dan golongan lain-lain atau penerima pendapatan (orang-orang cacat, jompo dan orang yang sudah pensiun). Ketiga golongan bukan angkatan kerja di atas juga disebut angkatan kerja potensial, karena golongan ini sewaktu-waktu dapat menawarkan jasannya untuk bekerja (Subandi: 2012).

Malthus dalam Mankiw (2003) sebagai pemikir klasik yang sangat berjasa dalam pengembangan pemikiran-pemikiran ekonomi. Malthus dalam karyanya Principles of Population. Dari buku tersebut akan dilihat bahwa meskipun Malthus termasuk salah satu pengikut Adam Smith, namun tidak semua pemikirannya sejalan dengan pemikiran Smith. Disatu pihak Smith optimis bahwa kesejahteraan umat manusia akan selalu meningkat sebagai dampak positif dari pembagian kerja dan spesialisasi. Sebaliknya, Malthus justru pesimis tentang masa depan umat manusia dan menentang gagasan Malthus. Malthus tidak percaya bahwa teknologi mampu berlomba dengan penduduk. Malthus juga berpendapat bahwa jumlah penduduk yang tinggi pasti mengakibatkan turunnya produksi per kepala. Dalam Essays on the Principles of Population (1796). Ia menguraikan bahwa satu satunya cara untuk menghindar dari malapetaka pertumbuhan penduduk adalah dengan melakukan kontrol atau pengawasan atas pertumbuhan penduduk. Bebrapa jalan keluar yang Malthus tawarkan adalah menunda usia perkawinan dan mengurangi jumlah anak. Pembatasan seperti ini disebut Malthus sebagai pembatasan moral. Jika hal ini tidak dilakukan, demikian ia menguraikan, persoalan ini akan diselesaikan secara alamiah, antara lain akan timbul perang, epidemi,kekurangan pangan dan sebagainya. 
Akan tetapi Schultz dalam Sandona (2013), Perkins et al., (2001), Welzel et.al (2002) dan Brata, (2004) mencoba mensintesa pandangan sebelumnya yang mengungkapkan bahwa bahwa Human Capital (HC) terdiri keterampilan, pengetahuan, dan kemampuan individu. Memaksimalkan HC memungkinkan individu untuk memaksimalkan penghasilan, memaksimalkan keuntungan perusahaan, dan untuk memaksimalkan kekayaan negara. Pembangunan manusia mencakup tiga dimensi pembangunan yakni: dimensi pembangunan sosial ekonomi, dimensi pembangunan kelembagaan politik, dan dimensi pembangunan kultural. Ketiga dimensi pembangunan ini, baik secara langsung maupun tidak langsung, memberikan sumbangan besar terhadap kebebasan seseorang yang diterjemahkan dalam bentuk human choice. Pengertian human choice merujuk kepada kemampuan yang dimiliki seseorang untuk memilih kehidupan yang diinginkan. Konsep ini juga dapat dimaknai sebagai pilihan untuk mengembangkan seluruh potensi dan kemampuan mereka dalam mendukung produktivitas dan kreativitas sesuai dengan kebutuhan dan minat mereka masing-masing. Dimensi pembangunan sosial ekonomi mencakup dan terkait dengan beberapa tema antara lain prestasi perekonomian, kenaikan taraf kesehatan, angka harapan hidup serta perluasan distribusi pendidikan.

Tingkat pembangunan manusia yang relatif tinggi akan mempengaruhi kinerja pertumbuhan ekonomi melalui kapabilitas penduduk dan konsekuensinya adalah peningkatan produktivitas dan kreativitas masyarakat. Dengan meningkatnya produktivitas dan kreativitas tersebut, penduduk dapat menyerap dan mengelola sumberdaya yang penting bagi pertumbuhan ekonomi. Keterkaitan pembangunan manusia dan pertumbuhan ekonomi dapat dipahami dari dua arah, yaitu pengaruh dari pertumbuhan ekonomi terhadap pembangunan manusia dan dari pembangunan manusia terhadap pertumbuhan ekonomi. Ada banyak alasan untuk meyakini bahwa ada hubungan timbal balik antara pembangunan manusia dan pertumbuhan ekonomi. Di satu sisi pertumbuhan ekonomi dapat dan selalu mendorong meningkatnya kualitas pendidikan, kesehatan dan standar nutrisi. Di sisi yang lain investasi pada pembangunan manusia akan mendorong pertumbuhan ekonomi, hal ini terjadi pada peningkatan produktivitas tenaga kerja. 


\section{Pengeluaran Pemerintah}

Keynes dalam Mankiw (2003) menyatakan bahwa pemerintah dapat melakukan campur tangan dalam perekonomian. Peranan pemerintah adalah untuk menstimulasi permintaan agregat. Kebijakan fiskal harus dapat digunakan sebagai stabilisator tingkat output dan employment. Disisi lain, dalam teori Aggregate Output Keynesian menyebutkan bahwa salah satu komponen yang membentuk PDB adalah pajak. Teori ini menjelaskan bahwa jika ada perubahan (kenaikan) pada penerimaan pajak, maka akan berdampak pada penurunan pada disposable income atau pendapatan yang siap untuk dibelanjakan, yang selanjutnya akan mempengaruhi konsumsi dari masyarakat. Dengan menurunnya konsumsi akibat kenaikan pajak, pada akhirnya akan berdampak pada penurunan PDB.

Namun, hal itu ditentang oleh Barro dalam Dumairy (1997) tentang argumen taxsmoothing, yang diperkenalkan dari model ini menyatakan bahwa kebijakan sebaiknya tetap netral selama siklus bisnis dan hanya merespon perubahan-perubahan yang tidak diantisipasi yang mempengaruhi konstrain anggaran pemerintah.

Akhirnya gagasan itu mencoba disentesa oleh Rostow dalam Musgrave (1989). Salah satu teori tentang pengeluaran pemerintah adalah model pembangunan perkembangan pengeluaran pemerintah. Model ini dikembangkan oleh Rostow yang menghubungkan perkembangan pengeluaran pemerintah dengan tahap-tahap pembangunan ekonomi yaitu tahap awal, tahap menengah dan tahap lanjut. Pada tahap awal perkembangan ekonomi, persentase investasi pemerintah terhadap total investasi besar sebab pada tahap ini pemerintah harus menyediakan prasarana seperti pendidikan, kesehatan dan transportasi. Pada tahap menengah pembangunan ekonomi, investasi pemerintah tetap diperlukan untuk meningkatkan pertumbuhan ekonomi agar dapat tinggal landas, namun pada tahap ini peranan investasi swasta sudah semakin besar. Peranan pemerintah tetap besar pada tahap menengah oleh karena peranan swasta yang semakin besar akan menimbulkan banyak kegagalan pasar dan juga menyebabkan pemerintah harus menyediakan barang dan jasa publik dalam jumlah yang lebih banyak. Selain itu pada tahap ini perkembangan ekonomi menyebabkan terjadinya hubungan antar sektor yang makin kompleks. Misalnya pertumbuhan ekonomi yang ditimbulkan oleh perkembangan sektor industri akan menimbulkan semakin tingginya pencemaran atau polusi. Pemerintah harus turun tangan mengatur dan mengurangi dampak negatif dari polusi. Pemerintah juga harus melindungi buruh dalam meningkatkan kesejahteraannya. Musgrave berpendapat bahwa dalam suatu 
proses pembangunan, investasi swasta dalam persentase terhadap PDB semakin besar dan persentase investasi pemerintah terhadap PDB akan semakin kecil. Pada tahap ekonomi lebih lanjut, Rostow mengatakan bahwa aktivitas pemerintah dalam pembangunan ekonomi beralih dari penyediaan prasarana ke pengeluaran-pengeluaran untuk aktivitas sosial, seperti program kesejahteraan hari tua dan pelayanan kesehatan masyarakat. Teori Rostow dan Musgrave adalah pandangan yang timbul dari pengamatan atas pengalaman pembangunan ekonomi yang dialami oleh banyak negara. Selain itu, tidak jelas apakah tahap pertumbuhan ekonomi terjadi dalam tahap demi tahap atau beberapa tahap dapat terjadi secara simultan.

\section{METODE PENELITIAN / METHODS}

Penelitian ini adalah penelitian yang menggunakan pendekatan kuantitatif. Pendekatan kuantitatif dilakukan untuk mengkaji pengaruh tenaga kerja, investasi swasta dan pengeluaran pemerintah terhadap pertumbuhan ekonomi dan kemiskinan di Kabupaten Sinjai. Untuk mengetahui pengaruh tersebut maka digunakan analisis Struktural Equation Models (SEM) dengan alat bantu Eviews. Jenis data yang digunakan dalam penelitian ini adalah data sekunder. Kebutuhan data sekunder yaitu data yang diperoleh dari sumbersumber yang berkaitan dengan pembangunan dan pertumbuhan ekonomi daerah. Pengumpulan data diperoleh melalui telaah kepustakaan dan hasil publikasi.

Berdasarkan penelitian terdahulu beserta tinjauan teoritis tentang variabel-variabel yang berpengaruh terhadap pertumbuhan ekonomi dan kemiskinan, maka hubungan tiap faktor dapat dijelaskan sebagai berikut:

Pertumbuhan ekonomi dinyatakan dalam persamaan $\mathrm{Y}=\mathrm{C}+\mathrm{I}+\mathrm{G}+(\mathrm{X}-\mathrm{M})$, artinya pertumbuhan ekonomi dipengaruhi oleh konsumsi Rumah Tangga (C), Investasi (I), Pengeluaran Pemerintah (G), dan Ekspor dan Impor (X-M). Besarnya pertumbuhan ekonomi sangat ditentukan oleh keempat komponen tersebut. Untuk penelitian ini, berusaha melihat pengaruh tenaga kerja dan pengeluaran pemerintah terhadap pertumbuhan ekonomi dan kemiskinan di Kabupaten Sinjai. Secara teoritis dikatakan tenaga kerja berpengaruh terhadap pertumbuhan ekonomi. Semakin tinggi kualitas tenag kerja suatu negara atau daerah maka akan semakin tinggi pula pertumbuhan ekonomi negara atau daerah tersebut, begitu pun sebaliknya. 
Pengeluaran pemerintah pun berpengaruh positif terhadap pertumbuhan ekonomi. Pengeluaran pemerintah berarti akan mendorong kesempatan kerja. Di bidang pendidikan pengeluaran pemerintah akan meningkatkan jumlah masyarakat yang bisa mendapatkan akses pendidikan akan bertambah. Meningkat kualitas pendidikan akan berpengaruh terhadap peningakatan pertumbuhan ekonomi. Begitu juga dengan alokasi anggaran sektor kesehatan yang tinggi akan berpengaruh terhadap banyaknya masyarakat yang akan mendapatkan layanan kesehatan. Kesehatan masyarakat yang meningkat berarti meningkatkan harapan hidup masyarakat. Harapan hidup masyarakat yang tinggi berimplikasi terhadap peningkatan kualitas tenaga kerja. Selanjutnya pertumbuhan ekonomi yang meningkat akan berpengaruh terhadap menurunnya angka kemiskinan.

Untuk mengetahui pengaruh tenaga kerja, investasi swasta dan pengeluaran pemerintah terhadap pertumbuhan ekonomi dan kemiskinan di Kabupaten Sinjai menggunakan analisis SEM. Adapun persamaan fungsional dalam model analisis SEM dapat dirumuskan sebagai berikut:

(1) $Y_{1}=f\left(X_{1}, X_{2}\right)$

(2) $Y_{2}=f\left(X_{1}, X_{2}, Y_{1}\right)$

Dimana :

$\mathrm{X}_{1} \quad=$ tenaga kerja (orang)

$\mathrm{X}_{2} \quad=$ pengeluaran pemerintah $(\mathrm{Rp})$

$\mathrm{Y}_{1} \quad=$ pertumbuhan ekonomi $(\%)$

$\mathrm{Y}_{2}=$ kemiskinan (\%)

Berdasarkan model fungsional di atas, maka dibentuk persamaan regresi sebagai berikut:

$Y_{1}=\ln a_{0}+a_{1} \ln X_{1}+a_{2} \ln X_{2}+\mu_{1}$

Untuk menghitung pengaruh tenaga kerja dan pengeluaran pemerintah terhadap pertumbuhan ekonomi dan kemiskinan maka persamaan (1.4) disubtitusi ke persamaan (1.5) dan persamaan.

$Y_{2}=\ln Y_{0}+Y_{1} \ln X_{1}+Y_{2} \ln X_{2}+Y_{3} Y_{1}+\mu_{2}$

$Y_{2}=\left(\ln Y_{0}+\ln a_{0} Y_{3}\right)+\left(Y_{1} \ln X_{1}+a_{1} Y_{3} \ln X_{1}\right)+\left(Y_{2} \ln X_{2}+a_{2} Y_{3} \ln X_{2}\right)+\left(\mu_{1} Y_{3}+\mu_{2}\right)$

$Y_{2}=\left(\ln Y_{0}+\ln a_{0} Y_{3}\right)+\left(Y_{1}+a_{1} Y_{3}\right) \ln X_{1}+\left(Y_{2}+a_{2} Y_{3}\right) \ln X_{2}+\left(\mu_{1} Y_{3}+\mu_{2}\right)$

$Y_{2}=\ln \theta_{0}+\theta_{1} \ln X_{1}+\theta_{2} \ln X_{2}+\mu_{3}$

\section{HASIL DAN PEMBAHASAN / DISCUSSION}


Salah satu indikator makro ekonomi yang bisa dijadikan rujukan untuk melihat adanya perbaikan kinerja sosial ekonomi daerah termasuk sebuah negara secara umum adalah jumlah penduduk yang bekerja. Semakin banyak yang berkerja berarti kinerja pembangunan di daerah atau negara tersebut adalah baik, begitupun sebaliknya. Sejak tahun 2011 sampai tahun 2015 terjadi peningkatan jumlah penduduk di Kabupaten Sinjai. Pada tahun 2011 jumlah penduduk masih berjumlah 233.200 jiwa dan pada tahun 2015 sudah mencapai 239.099 jiwa. Ini berarti ada peningkatan sebanyak 5899 jiwa. Meski mengalami peningkatan penduduk tapi peningkatannya tergolong masih rendah. Dalam lima tahun pertambahan penduduk hanya 5.899 jiwa atau meningkat sekitar 1.179 jiwa pertahun. Pertumbuhan jumlah penduduk yang lambat bisa dalam tinjauan pembangunan ekonomi dapat dinilai dari dua sisi yakni sisi positif dan negatifnya. Dari sisi positif dapat dijelaskan bahwa jumlah penduduk yang pertambahannya sedikit atau melambat akan membuat pembagian pendapatan akan lebih banyak dinikmati oleh masyarakat. Hal ini karena angka pembaginya tidak bertambah banyak, pada saat yang sama pendapatan ekonomi mengalami peningkatan. Ini pun bisa menjadi cerminan kesuksesan program pemerintah dalam hal menekan angka kelahiran, misalnya melalui program Keluarga Berencana (KB).

Sementara sisi negatifnya, pertumbuhan jumlah penduduk yang melambat, berarti akan mengurangi ketersediaan angkatan kerja. Pada saat yang sama pula akan mengurangi konsumsi yang akan berpengaruh terhadap pertumbuhan ekonomi yang menurun pula.

Selanjutnya mengenai jumlah penduduk yang bekerja juga terlihat jelas dalam lima tahun terakhir mengalami peningkatan. Peningkatannya sendiri terlihat fluktuatif. Pada tahun 2011 jumlah penduduk yang bekerja sebanya 95.654 jiwa. Kemudian mengalami peningkatan yang signifikan pada tahun 2012 menjadi 112.493 jiwa. Setelah itu mengalami penurunan pada tahun 2013 menjadi 110.349 jiwa. Pada tahun 2014 kembali mengalami peningkatan menjadi 112.021 jiwa, namun kembali mengalami penurunan pada tahun 2015 menjadi 106.909. Sebuah penurunan yang cukup drastis mencapai 5.112 jiwa. Angka yang tergolong cukup besar. Namun demikian jika dibandingkan dengan kondisi tahun 2011 atau lima tahun yang lalu jumlah penduduk bekerja di Kabupaten Sinjai masih mengalami peningkatan sebesar 11.255 jiwa. 
Ilyas, Pengaruh Tenaga Kerja, dan Pengeluaran ...

Fluktuasi jumlah penduduk yang bekerja harus tetap menjadi perhatian pemerintah. Mengingat di tahun terakhir yakni tahun 2015 justru mengalami penurunan yang cukup signifikan. Di saat yang sama jumlah penduduk mengalami peningkatan. Oleh karena itu pemerintah diharapkan mampu membuka lapangan kerja baru untuk menampung penduduk yang akan memasuki dunia kerja.

Salah satu indikator untuk melihat kinerja sosial ekonomi suatu daerah, apakah mengalami kenaikan atau sebaliknya, bisa dilihat dari persentase angka kemiskinannya. Jika dalam setiap tahun mengalami penurunan berarti ada perbaikan dalam kinerja sosial ekonomi daerah tersebut. Sebaliknya jika kemiskinan justru mengalami kenaikan berarti bisa dikatakan tidak terjadi perbaikan berarti dalam kinerja sosial ekonomi daerah tersebut. Berikut ini gambaran kemiskinan di Kabupaten Sinjai dalam lima tahun terakhir

Tabel 1 Jumlah Penduduk Miskin Di Kabupaten Sinjai

\begin{tabular}{ccc}
\hline Tahun & Jumlah Penduduk (Jiwa) & Jumlah Penduduk Miskin (Jiwa) \\
\hline 2011 & 233.200 & 22.310 \\
\hline 2012 & 234.886 & 21.510 \\
\hline 2013 & 236.497 & 24.300 \\
\hline 2014 & 238.099 & 22.630 \\
\hline 2015 & 239.099 & 21.900
\end{tabular}

Sumber: BPS Sinjai (data diolah)

Menurut tabel di atas sejak tahun 2011 sampai tahun 2015 secara konsisiten jumlah penduduk di Kabupaten Sinjai mengalami peningkatan. Sebaliknya jumlah penduduk miskin dalam lima tahun terakhir mengalami penurunan yang sifatnya fluktuatif. Pada tahun 2011 jumlah penduduk miskin sebanyak 22.310 jiwa, kemudia menurun menjadi 21.510 jiwa pada tahun 2012. Selanjutnya pada tahun 2013 mengalami peningkatan yang cukup signifikan menjadi 24.300 jiwa. pada tahun 2014 angka kemiskinan kembali mengalami penurunan menjadi 22.630 jiwa dan terakhir pada tahun 2015 juga mengalami penurunan menjadi 21.900 jiwa. Penurunan angka kemiskinan dalam lima tahun terakhir tergolong sangat klecil yakni hanya sebesar 410 jiwa. Belum lagi jika dibandingkan pada tahun 2012 angka kemiskinan telah mengalami penurunan menjadi 21.510 jiwa. Posisi ini belum bisa dicapai lagi sampai pada tahun 2015. 
Persentase angka kemiskinan di tahun 2015 yang mencapai 9,16 persen adalah angka yang cukup besar, mendekati double digit. Meski sedikit lebih rendah dengan angka kemiskinan nasional yang mencapai double digit atau di atas 10 persen. Namun demikian yang menjadi catatan kritis tentang kemiskinan di kabupaten Sinjai adalah selain angkanya yang masih tinggi juga pada persoalan penurunannya yang masih sangat rendah. Hanya 410 jiwa dalam lima tahun terakhir. Belum lagi jika dibandingkan dengan belanja pemerintah daerah yang justru setiap tahun mengalami peningkatan. Peningkatan belanja belum memberikan pengaruh signifikan terhadap penurunan angka kemiskinan.

Untuk melihat keseriusan pemerintah dalam mendorong pertumbuhan ekonomi serta memperbaiki kinerja sosial masyarakat bisa dilihat dari politik anggaran dalam APBD. Keberpihakan pemerintah bisa dilihat dari besaran alokasi anggarannya untuk Kabupaten Sinjai sendiri bisa dilihat pada tabel berikut ini:

Tabel 2 Pengeluaran Pemerintah Tahun 2011-2015

Tahun

Pengeluaran pemerintah (juta Rupiah

\begin{tabular}{ll}
\hline 2011 & 527.680 \\
\hline 2012 & 555.073 \\
\hline 2013 & 644.523 \\
\hline 2014 & 845.000 \\
\hline 2015 & 1.054 .000 \\
\hline
\end{tabular}

Sumber: BPS Sinjai (data diolah)

Berdasarkan tabel di atas terlihat jelas sejak tahun 2011 sampai tahun 2015 pengeluaran pemerintah mengalami peningkatan yang sangat signifikan. Pada tahun 2011 pengeluaran pemerintah baru sebesar Rp 527,680 milyar dan pada tahun 2015 sudah mencapai Rp. 1,054 triliun atau mengalami peningkatan hampir 2 kali lipat atau sebesar 50 persen. Peningkatan pengeluaran pemerintah dapat dikomparasikan dengan semakin meningkatnya pertumbuhan ekonomi di Kabupaten Sinjai di satu sisi dan tentunya semakin meningkatnya transfer pemerintah pusat.

Hasil Uji Statistik : Persamaan 1 Y1 = $\mathrm{f}(\mathrm{X} 1, \mathrm{X} 2)$. 


\section{Pengujian Hipotesis}

a. Koefisien Determinasi (R2)

Koefisien determinasi (R2) pada intinya mengukur seberapa jauh kemampuan model dalam menerangkan variasi variabel dependen. Nilai koefisien determinasi adalah nol dan satu. Nilai R2 yang kecil berarti kemampuan variabel-variabel independen dalam menjelaskan variasi variabel dependen amat terbatas. Nilai yang mendekati satu berarti variabel-variabel independen memberikan hampir semua informasi yang dibutuhkan untuk memprediksi variasi variabel dependen. Dari hasil regresi pengaruh variabel tenaga kerja dan pengeluaran pemerintah terhadap pertumbuhan ekonomi (Y1) diperoleh nilai R2 sebesar 0,786. Hal ini berarti variasi variabel independen (bebas) yaitu tenaga kerja dan pengeluaran pemerintah menjelaskan variasi variabel dependen (terikat) yaitu pertumbuhan ekonomi di Kabupaten Sinjai sebesar 78,6 persen. Adapun sisanya variasi variabel lain dijelaskan diluar model sebesar 21,4 persen.

b. Deteksi Signifikansi Simultan (Uji Statistik F)

Pengujian terhadap pengaruh semua variabel independen di dalam model dapat dilakukan dengan uji simultan (uji F). Uji statistik F pada dasarnya menunjukkan apakah semua variabel independen yang dimasukkan dalam model mempunyai pengaruh secara bersama-sama terhadap variabel dependen. Dari hasil regresi pengaruh tenaga kerja dan pengeluaran pemerintah terhadap pertumbuhan ekonomi di Kabupaten Sinjai, maka diperoleh F-tabel sebesar 3,14 ( $\mathrm{a}=10 \%$ dan $\mathrm{df}=15-2=13$ ) sedangkan F-statistik/Fhitung sebesar 22,035 dan nilai probabilitas F-statistik 0,000. Maka dapat disimpulkan bahwa variabel independen secara bersama-sama berpengaruh terhadap variabel dependen (F-hitung > F-tabel).

c. Deteksi Signifikansi Parameter Individual (Uji Statistik T)

Uji statistik t pada dasarnya menunjukkan seberapa jauh pengaruh masing-masing variabel independen secara individual dalam menerangkan variasi variabel dependen. Dari hasil regresi pengaruh tenaga kerja dan pengeluaran pemerintah terhadap pertumbuhan ekonomi di Kabupaten Sinjai, dengan $a=10 \%$ dan df = $13(n-k=15-2)$, maka diperoleh nilai ttabel sebesar 1,35017. Berdasarkan nilai t-tabel tersebut dan dengan asumsi t-statistik/thitung > t-tabel, variabel independen yang signifikan terhadap variabel pertumbuhan ekonomi adalah variabel pengeluaran pemerintah ( $t$-hitung $=2,758$ ).

Persamaan 2 Y2 $=f(X 1, X 2, Y 1)$

\section{Regression}




\section{Pengujian Hipotesis}

a.Koefisien Determinasi (R2)

Koefisien determinasi (R2) pada intinya mengukur seberapa jauh kemampuan model dalam menerangkan variasi variabel dependen. Nilai koefisien determinasi adalah nol dan satu. Nilai R2 yang kecil berarti kemampuan variabel-variabel independen dalam menjelaskan variasi variabel dependen amat terbatas. Nilai yang mendekati satu berarti variabel-variabel independen memberikan hampir semua informasi yang dibutuhkan untuk memprediksi variasi variabel dependen. Dari hasil regresi pengaruh variabel tenaga kerja dan pengeluaran pemerintah terhadap pertumbuhan ekonomi (Y1) diperoleh nilai R2 sebesar 0,785. Hal ini berarti variasi variabel independen (bebas) yaitu tenaga kerja, pengeluaran pemerintah, dan pertumbuhan ekonomi menjelaskan variasi variabel dependen (terikat) yaitu tingkat kemiskinan di Kabupaten Sinjai sebesar 78,5 persen. Adapun sisanya variasi variabel lain dijelaskan diluar model sebesar 21,5 persen.

\section{b.Deteksi Signifikansi Simultan (Uji Statistik F)}

Pengujian terhadap pengaruh semua variabel independen di dalam model dapat dilakukan dengan uji simultan (uji F). Uji statistik F pada dasarnya menunjukkan apakah semua variabel independen yang dimasukkan dalam model mempunyai pengaruh secara bersama-sama terhadap variabel dependen.

Dari hasil regresi pengaruh tenaga kerja, pengeluaran pemerintah, dan pertumbuhan ekonomi terhadap tingkat kemiskinan di Kabupaten Sinjai, maka diperoleh F-tabel sebesar 3,14 ( $a=10 \%$ dan $d f=15-2=13$ ) sedangkan F-statistik/F-hitung sebesar 13,372 dan nilai probabilitas F-statistik 0,000. Maka dapat disimpulkan bahwa variabel independen secara bersama-sama berpengaruh terhadap variabel dependen (F-hitung > F-tabel).

c.Deteksi Signifikansi Parameter Individual (Uji Statistik T)

Uji statistik t pada dasarnya menunjukkan seberapa jauh pengaruh masing-masing variabel independen secara individual dalam menerangkan variasi variabel dependen. Dari hasil regresi pengaruh tenaga kerja dan pengeluaran pemerintah terhadap pertumbuhan ekonomi di Kabupaten Sinjai, dengan $a=10 \%$ dan df $=13(n-k=15-2)$, maka diperoleh nilai t-tabel sebesar 1,35017. Berdasarkan nilai t-tabel tersebut dan dengan 
Ilyas, Pengaruh Tenaga Kerja, dan Pengeluaran ...

asumsi t-statistik/t-hitung > t-tabel, tidak ada variabel independen yang signifikan terhadap variabel kemiskinan di Kabupaten Sinjai.

\section{Pengaruh Tenaga Kerja Terhadap Pertumbuhan Ekonomi Di Kabupaten Sinjai}

Dari hasil uji statistik yang dilakukan dengan menggunakan program SPSS 16 ditemukan bahwa tenaga kerja tidak berpengaruh signifikan terhadap pertumbuhan ekonomi di Kabupaten Sinjai. Temuan ini berbeda dengan yang dikemukakan oleh Novita Linda Sitompul (2007), yang meneliti pengaruh investasi dan tenaga kerja terhadap PDRB Sumatera Utara yang menemukan bahwa jumlah tenaga kerja dan kondisi perekonomian berpengaruh positif terhadap pertumbuhan ekonomi Sumatera Utara dengan nilai koefisien determinasi sebesar 98,39 persen. Jumlah tenaga kerja dapat berpengaruh positif dan negatif terhadap pertumbuhan ekonomi. Akan berpengaruh positif jika jumlah tenaga kerja yang banyak tersebut disertai dengan kualitas yang tinggi sehingga bisa mendorong pertumbuhan ekonomi. Namun jika sebaliknya maka jumlah tenaga kerja akan berpengaruh negatif terhadap pertumbuhan ekonomi. Tenaga kerja merupakan suatu faktor yang mempengaruhi output suatu daerah. angkatan kerja yang besar akan terbentuk dari jumlah penduduk yang besar. masalah kependudukan yang timbul bukan karena banyaknya jumlah anggota keluarga, melainkan karena mereka terkonsentrasi pada daerah perkotaan saja sebagai akibat dari cepatnya laju migrasi dari desa ke kota. Pertumbuhan penduduk yang cepat dapat mendorong timbulnya masalah keterbelakangan dan membuat prospek pembangunan menjadi semakin jauh (Todaro, 2002).

Tenaga kerja tidak berpengaruh signifikan terhadap pertumbuhan ekonomi di Kabupaten Sinjai hal ini dapat dilihat dari hasil temuan penelitian, dimana didapatkan dalam lima tahun terakhir, terhitung sejak tahun 2011 sampai tahun 2015 secara konstan pertumbuhan jumlah penduduk mengalami kenaikan. Sementara itu terjadi sebaliknya pada angka tenaga kerja yang justru mengalami kondisi fluktuatif dalam lima tahun terakhir. Pada tahun 2015 jumlah tenaga kerja justru mengalami penurunan yang cukup signifikan menjadi 106.909 jiwa padahal tahun sebelumnya mencapai angka 112.021 jiwa. Penurunan tenaga kerja inilah yang menjadi penyebab sehingga tenaga kerja tidak berpengaruh signifikan terhadap pertumbuhan ekonomi Kabupaten Sinjai.

\section{Pengaruh Pengeluaran Pemerintah Terhadap Pertumbuhan Ekonomi Di Kabupaten Sinjai}

Berdasarkan uji statistik yang dilakukan ditemukan bahwa pengeluaran pemerintah berpengaruh terhadap pertumbuhan ekonomi Sinjai. Hal ini sejalan dengan hipotesis yang diajukan. Pengaruh signifikan ini tercermin dari data pengeluaran pemerintah yang setiap 
tahun mengalami peningkatan yang signifikan dalam lima tahun terakhir. Pada tahun yang sama angka pertumbuhan ekonomi Kabupaten Sinjai pun mengalami peningkatan. Pengeluaran pemerintah dalam arti rill dapat dipakai sebagai indikator besarnya kegiatan pemerintah yang dibiayai oleh pengeluaran pemerintah. Semakin besar dan banyak pengeluaran pemerintah semakin besar pula pengeluaran pemerintah yang bersangkutan. Menurut Wijaya (2000), pengeluaran pemerintah mempunyai efek pengganda (multiplier effect) dan merangsang kenaikan pendapatan nasional dan akan menaikkan pendapatan serta produksi secara berganda sepanjang perekonomian belum mencapai tingkat kesempatan kerja penuh (full employment) karena ia akan menaikan permintaan agregatif didasarkan pada anggapan bahwa pengeluaran pemerintah tidaklah pada proyek-proyek yang dapat menghalangi atau menggantikan investasi sektor swasta.

Oleh karena itu pengeluaran pemerintah mempunyai hubungan yang sangat signifikan terhadap perekonomian, khususnya sektor rill. Signifikansi tersebut tercermin dari kontribusinya terhadap Produk Domestik Bruto. Kebijakan fiskal suatu negara merupakan instrumen untuk melaksanakan fungsi stabilisasi, distribusi dan alokasi yang diarahkan pada stimulus pertumbuhan ekonomi dan mendorong penciptaan lapangan kerja.

\section{Pengaruh Pertumbuhan Ekonomi Terhadap Kemiskinan Di Kabupaten Sinjai}

Dari hasil uji statistik dengan menggunakan program SPSS 16 ditemukan bahwa hubungan antara pertumbuhan ekonomi dan kemiskinan adalah negatif $(-0,460)$. Hubungan yang negatif menunjukkan bahwa ketika pertumbuhan ekonomi mengalami kenaikan maka angka kemiskinan akan mengalami penurunan. Begitu pun sebaliknya ketika pertumbuhan ekonomi mengalami penurunan maka akan berpengaruh terhadap meningkatnya angka kemiskinan. Pertumbuhan ekonomi angka mendorong perbaikan ekonomi di daerah misalnya mendorong meningkatnya angka tenaga kerja, daya beli masyarakat yang meningkat dan sebagainya. Jika ini yang terjadi maka angka kemiskinan pasti akan mengalami penurunan. Hasil uji statistik ini bisa dikomparasikan dengan data empiris yang menunjukkan bahwa dalam lima tahun terakhir pertumbuhan ekonomi mengalami peningkatan pada saat yang sama angka kemiskinan mengalami penurunan. Hasil penelitian ini juga menunjukkan bahwa hipotesis yang diajukan yakni pertumbuhan ekonomi berpengaruh terhadap penurunan kemiskinan dapat diterima. 


\section{KESIMPULAN / CONCLUSION}

Kesimpulan dari penelitian ini adalah tenaga kerja tidak berpengaruh signifikan terhadap pertumbuhan ekonomi. Sementara pengeluaran pemerintah berpangaruh positif dan signifikan terhadap pertumbuhan ekonomi. Selanjutnya pertumbuhan ekonomi berpengaruh terhadap kemiskinan, dan hubungannya negatif, artinya ketika pertumbuhan ekonomi mengalami peningkatan maka akan menurunkan angka kemiskinan begitupula sebaliknya.

\section{DAFTAR PUSTAKA / REFERENCES}

Brata, Aloysius Gunadi, 2004. Analisis Hubungan Imbal Balik Antara Pembangunan Manusia dan Kinerja Ekonomi Daerah Tingkat II di Indonesia. Yogyakarta: Lembaga Penelitian - Universitas Atma Jaya.

Dumairy. 1997. Perekonomian Indonesia. Jakarta: Erlangga.

Mankiw, N. Gregory. 2003. Pengantar Ekonomi. Jakarta: Erlangga

Musgrave, R. A., \& Musgrave, P. B. 1989. Public Finance in Theory and Practice, 5th ed. McGraw-Hill.

Perkins et al., 2001. Economics Of Development. Fifth Edition.New York: W.W. Norton \& Company, Inc.

Sandona, Luca. 2013. Broadening Neoclassical Human Capital Theory for the Attainment of Integral Human Development. Journal of Markets \& Morality Volume 16, No. $1 \mathrm{Hal}$. 25-26.

Subandi. 2012. Sistem Ekonomi Indonesia. ALFABETA. Bandung.

Sukirno, Sadono. 1994. Pengantar Teori Makro Ekonomi. PT. RajaGrafindo. Jakarta Undang-Undang Republik Indonesia Nomor 32 Tahun 2004 tentang Pemerintahan Daerah. Undang-Undang Republik Indonesia Nomor 33 Tahun 2004 tentang Perimbangan Keuangan antara Pemerintah Pusat dan Pemerintah Daerah.

Todaro, M.P and S.C.Smith. 2002. Economic Development, 8 edition. United Kingdom: Pearson Addison Weasley.

Todaro, Michael P. and Smith Stephen C. 2003. Economic Development. Eighth Edition. United Kingdom: Pearson Education Limited

Welzel, Christian, et.al. 2002. The Theory of Human Development A Cross Cultural Analysis. University of Calivornia, Irvine. 